\title{
Investigation of droplet impact on inclined fabric based on CMOS imaging technology and FSI numerical method
}

\author{
DOI: $10.35530 / I T .071 .06 .1730$
}

\section{ABSTRACT - REZUMAT}

\section{Investigation of droplet impact on inclined fabric based on CMOS imaging technology and FSI numerical method}

In order to study the impact characteristics of droplet on inclined fabric, the relevant experiment was setup in this paper. The process of a single droplet $(2.12 \mathrm{~mm})$ impacting inclined fabric $\left(45^{\circ}\right)$ was captured by CMOS (Complementary Metal-Oxide Semiconductor) imaging technology. It could be found that there was a second impact phenomenon during spreading stage, which was very different from impacting horizontal fabric. Then a two-way coupling method was used to simulate that impacting process. The numerical results were basically consistent with the experimental results. In addition, the reaction force and vibration characteristics of fabric which couldn't be collected by experiments were also obtained. Finally, the effect of inclination angle on impact characteristics was analyzed by numerical method. The bigger the inclination angle was, the longer the stability time of droplet was, and the smaller the reaction force on fabric was. The change law conformed to the momentum theorem. The method and conclusions could provide some references for the design of parachute system.

Keywords: CMOS, aeronautical fabric, fabric response, two-way coupling, polyamide

\section{Analiza impactului picăturilor pe suprafața țesăturii înclinate pe baza tehnologiei de imagistică CMOS și a metodei numerice FSI}

În cadrul acestei lucrări a fost realizat un experiment relevant, pentru a studia caracteristicile de impact ale picăturii pe țesătura înclinată. Impactul unei singure picături $(2,12 \mathrm{~mm})$ care intră în contact cu suprafața țesăturii înclinate $\left(45^{\circ}\right)$ a fost surprins de tehnologia de imagistică CMOS (Semiconductor complementar metal-oxid). S-a putut constata că a existat un al doilea fenomen de impact în etapa de răspândire, care a fost foarte diferit de impactul asupra țesăturii orizontale. Apoi, a fost utilizată o metodă de cuplare bidirecțională pentru a simula acel proces de impact. Rezultatele numerice au fost practic conforme cu rezultatele experimentale. În plus, au fost obținute și forța de reacție și caracteristicile de vibrație ale țesăturii, care nu au putut fi colectate prin experimente. În cele din urmă, influența unghiului de înclinare asupra caracteristicilor de impact a fost analizată prin metodă numerică. Cu cât unghiul de înclinare a fost mai mare, cu atât a fost mai mare și timpul de stabilitate al picăturii, iar forța de reacție pe țesătură este mai redusă. Legea schimbării s-a conformat teoremei impulsului. Metoda și concluziile ar putea oferi câteva referințe pentru proiectarea sistemului unei parașute.

Cuvinte-cheie: CMOS, țesătură pentru domeniul aeronautic, răspunsul materialului textil, cuplare bidirecțională, poliamidă

\section{INTRODUCTION}

Parachute is a kind of important aerodynamic deceleration equipment in aerospace field. However, in some bad weather, droplets impingent will seriously affect the deceleration effect of parachute system and reduce the probability of success in life saving. At present, many scholars have carried out a large number of researches on droplet impacting on rigid objects. Sikalo et al. investigated the effects of velocity, viscosity, surface wettability and roughness on impacting processes [1-3]. Chen et al replaced the impacted object with a cylinder or sphere, and the effect of different geometric characteristics on impacting processes was investigated [4]. Moita et al. investigated the heat transfer on impacting behavior [5-6]. However, the processes of droplets impact on porous media were more complex than on nonporous media. In addition to the known spreading stage and recoiling stage, there was also process of liquid absorption by porous media. Reis et al. used MAC (Marker and Cell) method to track the position and shape of liquid region [7]. Anderson used onedimensional immersion/deformation model to investigate the deformation of porous media [8]. Other scholars applied VOF (Volume of Fluid) method to simulate the spreading and absorbing behaviors of droplets on porous substrates [9-10].

Although the fabric is a typical porous material, the droplet impingement could cause material deformation, and the fabric deformation will interact with droplet deformation. However, the nature of fluid structure interaction mechanics has not been taken into account in the above studies. In addition, the effect of inclination angle on impacting processes has not been reported publicly. Therefore, the experiment used to capture the process of droplet impacting on inclined fabric was built based on CMOS imaging technology in this paper. Then a two-way coupling 
numerical method was used to obtain the data of vibration characteristics and reaction force.

\section{EXPERIMENT SETUP}

Figure 1 is the schematic diagram of the experiment. The height of syringe needle could be adjusted to obtain the initial impact velocity. The magnetic bases are used to suspend and fix the fabric, and adjust the inclination angle of the fabric. The cold light source is used for imaging illumination. The high speed camera (512*512 dpi, $3000 \mathrm{fps}$ ) based on CMOS imaging technology is used to record the impacting process. The computer is used to control the syringe pump to produce the droplet and record the experimental data.

According to the Pu's analysis of rain spectrum [11], it could be found that the droplets with diameter from $1 \mathrm{~mm}$ to $3 \mathrm{~mm}$ contribute most to rainfall intensity and water content. In addition, the steady dropping speed of parachute is $6 \mathrm{~m} / \mathrm{s}$. When the droplet's diameter is less than $1.9 \mathrm{~mm}$, the steady dropping speed is less than $6 \mathrm{~m} / \mathrm{s}$, and the probability of droplet impact on the canopy is smaller. Therefore, the impacting process of droplet with a diameter of $2.12 \mathrm{~mm}$ (the corresponding steady dropping velocity is $6.77 \mathrm{~m} / \mathrm{s}$ [11]) is investigated, and the initial relative impact velocity is $0.77 \mathrm{~m} / \mathrm{s}$ in this paper.

In this paper, the 66 type polyamide grid silk is taken as the research object. The bottom side of the fabric specimen is coated by silica gel. The permeability coefficient $\alpha$ and pressure drop coefficient $C_{2}$ are $1.5 \mathrm{E}-12 \mathrm{~m}^{2}$ and $2.5 \mathrm{E} 8 \mathrm{~m}^{-1}$ respectively. The thickness of fabric specimen is $0.08 \mathrm{~mm}$. The test bench and specimen are shown in figure 2.

\section{MODEL DEVELOPMENT}

In this paper, the VOF model is used to calculate the fluid field. Here the air is taken as main phase and water is the secondary phase. The control equations are as follows:

$$
\begin{gathered}
\frac{\partial\left(\alpha_{w} \rho_{w}\right)}{\partial t}+\nabla \cdot\left(\alpha_{w} \rho_{w} v_{w}\right)=0 \\
\frac{\partial(\rho \boldsymbol{v})}{\partial t}+\nabla \cdot(\rho \boldsymbol{v} \boldsymbol{v})= \\
=-\nabla \rho+\nabla \cdot\left[\mu\left(\nabla v+\nabla \boldsymbol{v}^{T}\right)\right]+\rho \boldsymbol{g}+\boldsymbol{F}+\boldsymbol{S}
\end{gathered}
$$

where $\alpha_{w}$ is the volume fraction of water, $\rho$ - density, $\boldsymbol{v}$ - velocity vector, $t$ - time, $\mu$ - dynamic viscosity, $\boldsymbol{g}$ - gravity vector, $\boldsymbol{F}$ - additional momentum source term caused by surface tension [12], $\boldsymbol{S}$ - the term caused by porous media. Geometry reconstruction method is applied to deal with the interface between different phases.

Here, the turbulence model is not considered because the Reynolds number is small. Meanwhile, the energy equation is not needed to be solved because the thermodynamic problem is not involved. In this paper the PISO (Pressure Implicit Split Operator) algorithm is used to solve the above equations.

The structural domain is calculated by Finite Element Method. The control equation is as follows:

$$
\begin{aligned}
& {[\boldsymbol{M}]\{\ddot{x}\}+[\boldsymbol{C}]\{\dot{x}\}+} \\
& +[\boldsymbol{K}]\{x\}=\{\boldsymbol{F}(t)\}
\end{aligned}
$$

where $[\boldsymbol{M}]$ is mass matrix, $[\boldsymbol{C}]$ - damping matrix, $[K]$ - stiffness matrix, $x$ - node displacement vector, $\{\boldsymbol{F}(t)\}$ - load vector. Here, the

Fig. 2. The experiment setup: $a$ - test bench; $b$ - fabric specimen 
Newark algorithm is used to solve the structural domain.

In this paper, the two-way coupling is realized by the separation method [13]. In each time step, the flow field is calculated first, and the coupling force is taken as boundary condition to calculate the structural domain. Then the displacement is used to adjust the flow field grids. The coupling calculation will continue

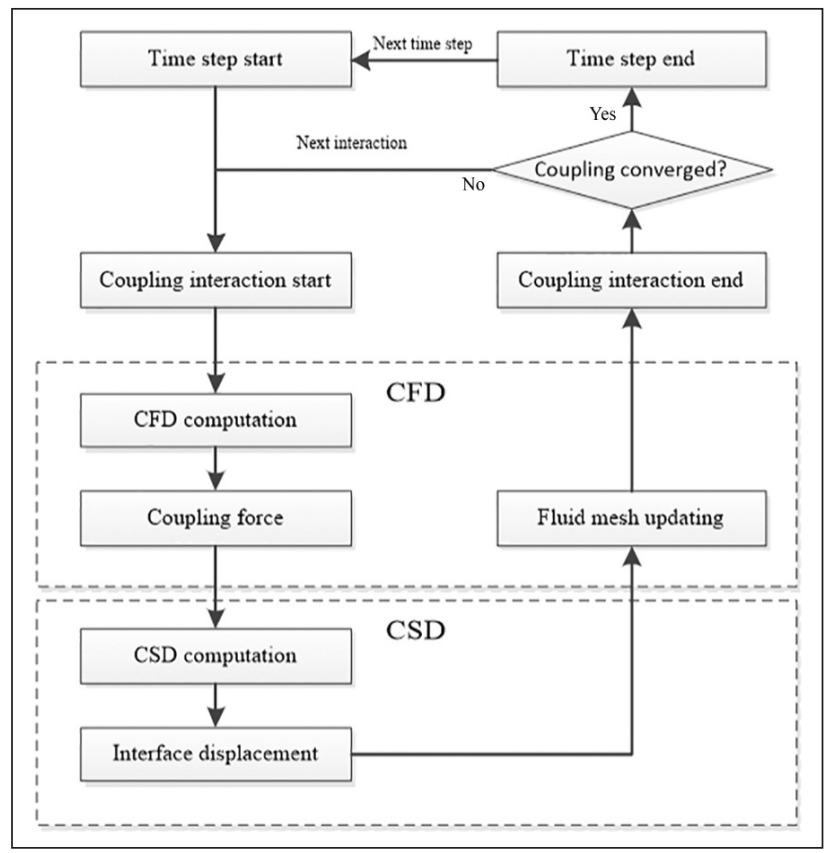

Fig. 3. The diagrammatic sketch of two-way coupling

until the results converge, and then the coupling calculation of the next time step will begin (figure 3 ).

In order to save computational resources, a symmetrical model is established (figure 4). Then 1,500,287 grids are used to discretize the flow field, and 24,241 grids are used to discretize the struc-

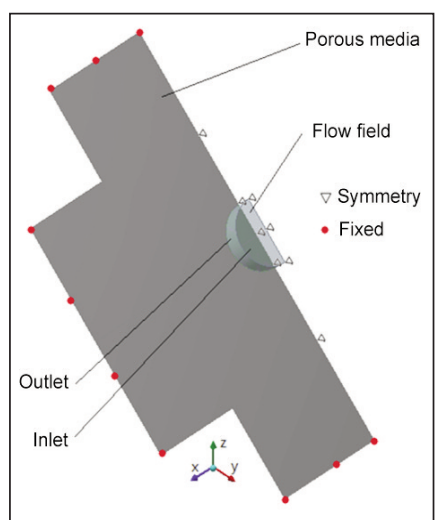

Fig. 4. The flow field model and structure model

\begin{tabular}{|c|c|c|}
\hline \multicolumn{3}{|c|}{ PARAMETERS OF FLOW FIELD } \\
\hline \multirow{2}{*}{ Boundary conditions } & Velocity inlet (m/s) & 0 \\
\hline & Pressure outlet $(\mathrm{Pa})$ & 0 \\
\hline \multirow{2}{*}{ Properties of air } & Density $\left(\mathrm{kg} / \mathrm{m}^{3}\right)$ & 1.204 \\
\hline & Viscosity $(\mathrm{Pa} \cdot \mathrm{s})$ & $1.82 \mathrm{E}-5$ \\
\hline \multirow{4}{*}{ Properties of droplet } & Diameter $(\mathrm{m})$ & $2.12 \mathrm{E}-3$ \\
\hline & Density $\left(\mathrm{kg} / \mathrm{m}^{3}\right)$ & 998 \\
\hline & Surface tension $(\mathrm{N} / \mathrm{m})$ & $7.4 \mathrm{E}-2$ \\
\hline & Viscosity $(\mathrm{Pa} \cdot \mathrm{s})$ & $1.01 \mathrm{E}-3$ \\
\hline
\end{tabular}

ture. While the calculation parameters are shown in table 1.

\section{RESULTS AND DISCUSSION}

Figure 5 is the droplet shape comparison between experimental and numerical results. It could be found that the whole impact process also can be divided into colliding stage $(0-0.333 \mathrm{~ms})$, spreading stage (0.333-15 ms), recoiling stage (15-36 ms) and oscillating stage (after $36 \mathrm{~ms}$ ).

Colliding stage $(0-0.333 \mathrm{~ms})$ : The duration of this stage is very short. The droplet begins to contact the fabric, and keep spherical shape basically.

Spreading stage $(0.333-15 \mathrm{~ms})$ : This stage is the most complex stage of the whole impacting process. At the beginning of this stage, droplet could maintain symmetrical shape (figure 6,a). But the droplet begins to slide to lower position under the action of gravity (figure 6,b). Meanwhile, the liquid velocity decreased gradually from the top to the bottom due to the viscous force, the upper liquid part of droplet keeps gathering to the lower position by gravity force. The droplet shows serious asymmetry (figure 6,c). Then the height begins to increase (figure 6,d). At about $15 \mathrm{~ms}$, the upper part of droplet collapse, and the droplet partially impact on the fabric again (figure 6,e). Recoiling stage (15-36 ms): After the second impact on the fabric, the bottom of the droplet begins to stabilize. While the upper liquid of the droplet begins to rebound in reverse (figure $6, f$ ).

Oscillating stage (after $36 \mathrm{~ms}$ ): At $36 \mathrm{~ms}$, the upper liquid of the droplet begins to move downward again. Droplet begins to stabilize gradually due to the constant dissipation of kinetic energy (figure $6, g$ ).

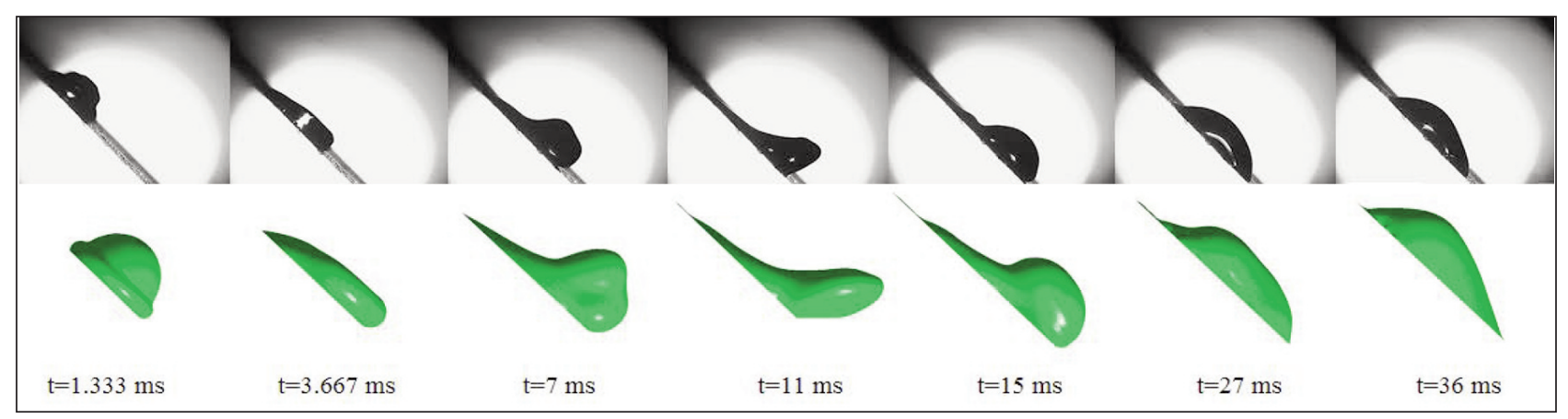

Fig. 5. The comparison between experimental and numerical results 


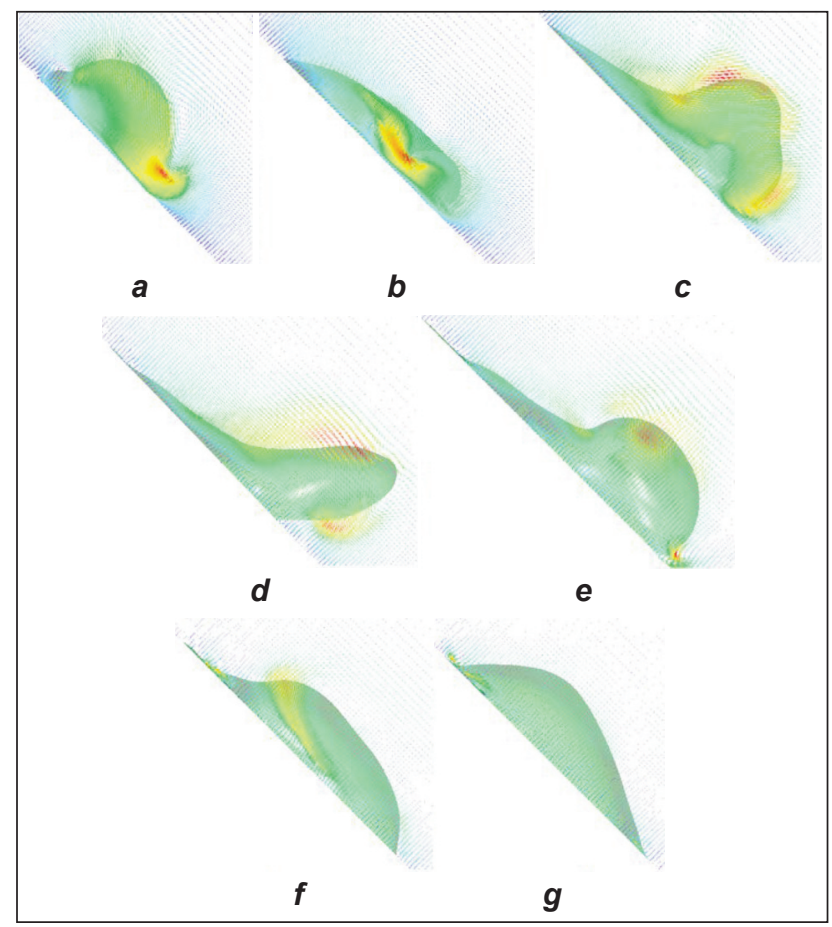

Fig. 6 . The velocity vector of flow field: $a-1.333 \mathrm{~ms}$; $b-3.667 \mathrm{~ms} ; c-7 \mathrm{~ms} ; d-11 \mathrm{~ms}$; e- $15 \mathrm{~ms}$; $f-27 \mathrm{~ms} ; g-36 \mathrm{~ms}$

Figure 7 shows the change of spreading factor. It could be found that the numerical results are basically consistent with the experimental results. After the droplet contact the fabric, it spread rapidly. At $8 \mathrm{~ms}$, the spreading factor is gradually stable and tends to shrink due to the viscous resistance acts on the bottom of the droplet. Meanwhile, the liquid on the upper part of the droplet continuously gathers to one side and causes the collapse at about $15 \mathrm{~ms}$ (figure 5). The secondary impact causes instantaneous increase of spreading factor. In the recoiling stage, the spreading factor changes steadily.

In addition, the processes of droplets impact on fabric with different inclination angles are also simulated. It could be found that the smaller the inclination angle is, the earlier the droplet reaches its maximum

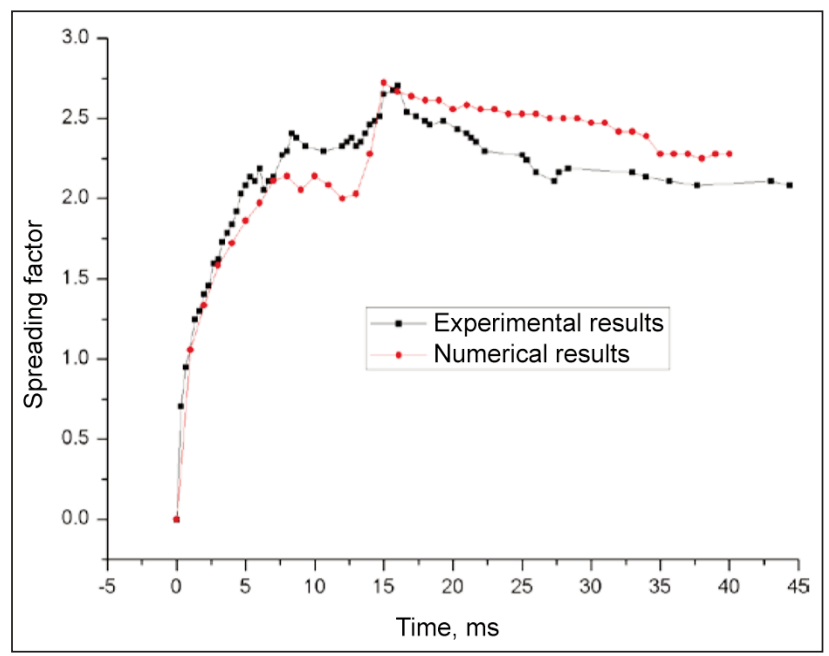

Fig. 7. The comparison of spreading factor spreading factor, and the smaller the maximum spreading factor is. Under the same conditions, the bigger the inclination angle is, the more severe the droplet deformation is and the longer the continuous deformation time is (figure $8, a$ ).

Figure $8, b$ shows the comparison of the reaction force. The smaller the inclination angle is, the smaller the horizontal force ( $Y$ direction) is, and the larger the vertical force $(Z$ direction) is. When the inclination

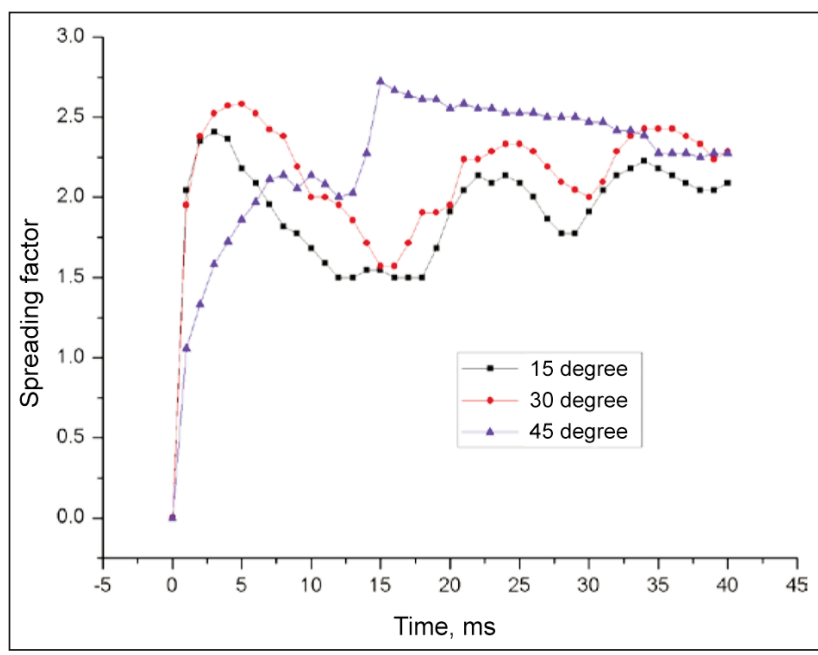

a
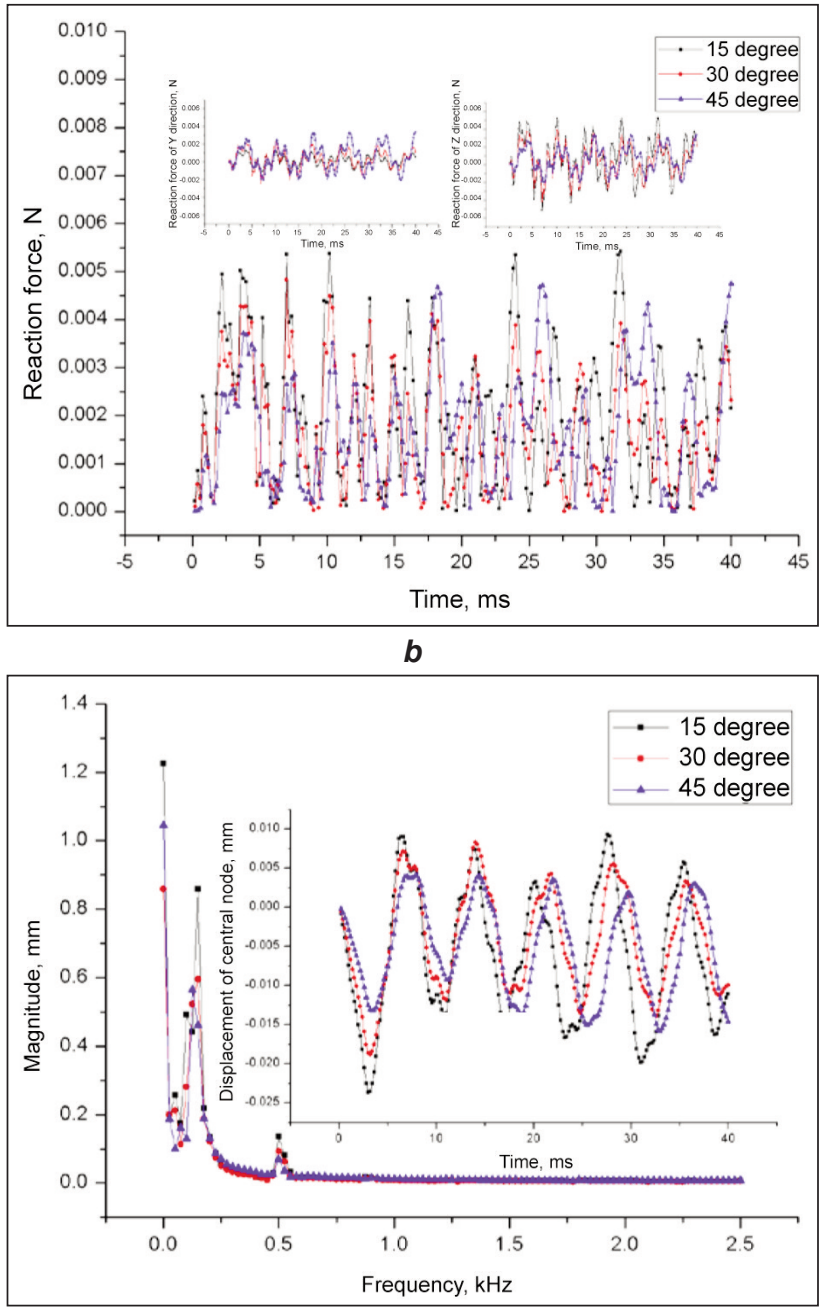

c

Fig. 8. The effect of inclination angle on impacting process: $a$ - spreading factor; $b$ - reaction force; $c$ - amplitude-frequency characteristic 
angle is 45 degree, the reaction forces of fabric in horizontal and vertical directions are almost the same. Generally speaking, the smaller the inclination angle is, the shorter the change time of droplet velocity is, and the larger the reaction force is. The above change law basically satisfies the momentum theorem $(F \cdot t=m \cdot \Delta v)$.

Figure $8, c$ shows the comparison of amplitude-frequency characteristic of specimen's center node. It could be found the inclination angle has little effect on fabric vibration. But the smaller the inclination angle is, the larger the amplitude is.

\section{CONCLUSIONS}

In this paper, the experiment of droplet impact on inclined fabric was setup. The impacting process was captured based on CMOS imaging technology. It could be found that the process could also be divided into colliding stage, spreading stage, recoiling stage and oscillating stage. However, the spreading stage is complex and there was a secondary impact phenomenon. In addition, a two-way coupling numerical method was used to obtain the data that can't be collected by the experiment. At last, the effect of inclination angle on impacting processes was analyzed. The experimental and numerical methods described in this paper could provide some reference for the design of parachute system.

\section{ACKNOLEDGEMENTS}

This work was supported by Natural Science Foundation of Jiangxi Province of China No. 20181BAB211004 and No. 20192ACBL20044.

\section{REFERENCES}

[1] Sikalo, S., Tropea, C., Ganic, E.N., Dynamic wetting angle of a spreading droplet, In: Experimental Thermal and Fluid Science, 2005, 29, 7, 795-802

[2] Wang, M.J., Lin, F.H., Ong, J.Y., Lin, S.Y., Dynamic behaviors of droplet impact and spreading-Water on glass and paraffin. In: Colloids \& Surfaces A Physicochemical \& Engineering Aspects, 2009, 339, 1, 224-231

[3] Bi, F.F., Guo, Y.L., Shen, S.Q., Chen, J.X., Li, Y.Q., Experimental study of spread characteristics of droplet impacting solid surface, In: Acta Physica Sinica, 2012, 61, 18, 27-32

[4] Chen, R.H., Wang, H.W., Effects of tangential speed on low-normal - speed liquid drop impact on a non-wettable solid surface, In: Experiments in Fluids, 2005, 39, 4, 754-760

[5] Moita, A., Moreira, A.L.N., Drop impacts onto cold and heated rigid surfaces: Morphological comparisons, disintegration limits and secondary atomization, In: International Journal of Heat \& Fluid Flow, 2007, 28, 4, 735-752

[6] Blake, J., Thompson, D., Raps, D., Strobl, T., Simulating the freezing of supercooled water droplets impacting a cooled substrate, In: AIAA Journal, 2015, 53, 7, 1725-1739

[7] Reis, N.C., Griffiths, R.F., Santos, J.M., Numerical simulation of the impact of liquid droplets on porous surfaces, In: Journal of Computational Physics, 2004, 198, 2, 747-770

[8] Anderson, D.M., Imbibition of a liquid droplet on a deformable porous substrate, In: Physics of Fluids, 2005, 17, 8, 087104

[9] Choi, M., Son, G., Shim, W., A level-set method for droplet impact and penetration into a porous medium, In: Atomization Sprays, 2017, 145, 153-166

[10] Alama, P., Toivakkaa, M., Backfolk, K., Sirvio, P., Impact spreading and absorption of Newtonian droplets on topographically irregular porous materials, In: Chemical Engineering Science, 2007, 62, 12, 142-3158

[11] Pu, J.P., Zhang, H., Zhou, X., Zhang, H.H., Wang, K.F., Comparative analysis on rain spectrum characteristics of deep convective cloud and its radar reflectivity, In: Journal of Meteorological Sciences, 2012, 32, 3, 253-259

[12] Brackbill, J.U., Kothe, D.B., Zemach, C., A continuum method for modeling surface tension, In: Journal of Computational Physics, 1992, 100, 2, 335-354

[13] Liu, B., Yan, Q., Wei, W., Numerical investigations of the flow induced oscillation of a torque converter, In: Engineering Applications of Computational Fluid Mechanics, 2018, 12, 1, 270-281

\section{Authors:}

\section{SHUHUA BAI, HAN CHENG}

Nanchang Institute of Technology, No. 901 Hero Avenue, Changbei Economic Development Zone, 330044, Jiangxi Nanchang, China

e-mail: 281440743@qq.com

Corresponding author:

HAN CHENG

e-mail: chenghanstorm@sina.com 